\title{
MicroRNAs for podocyte injury in diabetic nephropathy
}

\author{
Yoshiyuki Morishita \\ Division of Nephrology, Department of Integrated Medicine, Saitama Medical Center, Jichi Medical University, Saitama, Japan \\ Correspondence to: Yoshiyuki Morishita, MD, PhD. Division of Nephrology, Department of Integrated Medicine, Saitama Medical Center, Jichi \\ Medical University, 1-847, Amanuma, Omiya-ku, Saitama, Saitama 330-8503, Japan. Email: ymori@jichi.ac.jp.
}

Submitted Mar 03, 2021. Accepted for publication Mar 28, 2021.

doi: 10.21037/atm-21-1005

View this article at: http://dx.doi.org/10.21037/atm-21-1005

Diabetic nephropathy is one of critical complications of diabetes mellitus. It can progress to end-stage renal disease, which requires renal replacement therapy. Podocyte injury contributes to the development and progression of diabetic nephropathy $(1,2)$. However, the pathogenesis and regulatory molecules for podocyte injury have not been fully clarified.

MicroRNAs are small, non-coding, single-stranded RNAs that have been identified as essential regulators for the expression levels of many target mRNAs through degradation or suppression of translation by RNA interference (3). Although some microRNAs that regulate podocyte injury in diabetic nephropathy have been reported (4), further studies are warranted because many unreported microRNAs and their target mRNAs may play pivotal roles for podocyte injury in diabetic nephropathy.

Li et al. (5) showed that the microRNA-30 family members contribute to podocyte injury in diabetic nephropathy through the regulation of apoptosis and endoplasmic reticulum stress by modulating the expression level of connexin-43, an essential molecule for coordinated kidney function in cultured podocyte cells in vitro and diabetic nephropathy model rats in vivo.

These findings encourage further progression in studies on microRNAs for podocyte injury in diabetic nephropathy. The findings may also lead to the development of new pharmacological drugs and the identification of novel biomarkers for podocyte injury in diabetic nephropathy.

\section{Acknowledgments}

Funding: None.

\section{Footnote}

Provenance and Peer Review: This article was commissioned by the editorial office, Annals of Translational Medicine. The article did not undergo external peer review.

Conflicts of Interest: The author has completed the ICMJE uniform disclosure form (available at http://dx.doi. org/10.21037/atm-21-1005). The author has no conflicts of interest to declare.

Ethical Statement: The author is accountable for all aspects of the work in ensuring that questions related to the accuracy or integrity of any part of the work are appropriately investigated and resolved.

Open Access Statement: This is an Open Access article distributed in accordance with the Creative Commons Attribution-NonCommercial-NoDerivs 4.0 International License (CC BY-NC-ND 4.0), which permits the noncommercial replication and distribution of the article with the strict proviso that no changes or edits are made and the original work is properly cited (including links to both the formal publication through the relevant DOI and the license). See: https://creativecommons.org/licenses/by-nc-nd/4.0/.

\section{References}

1. Susztak K, Raff AC, Schiffer M, et al. Glucose-induced reactive oxygen species cause apoptosis of podocytes and podocyte depletion at the onset of diabetic nephropathy. Diabetes 2006;55:225-33.

2. Shankland SJ. The podocyte's response to injury: role in proteinuria and glomerulosclerosis. Kidney Int 2006;69:2131-47. 
3. Ambros V. The functions of animal microRNAs. Nature 2004;431:350-5.

4. Ishii H, Kaneko S, Yanai K, et al. MicroRNAs in Podocyte Injury in Diabetic Nephropathy. Front Genet 2020;11:993.
5. Li M, Ni W, Zhang M, et al. MicroRNA-30/Cx43 axis contributes to podocyte injury by regulating ER stress in diabetic nephropathy. Ann Transl Med 2020;8:1674.

Cite this article as: Morishita Y. MicroRNAs for podocyte injury in diabetic nephropathy. Ann Transl Med 2021;9(10):829. doi: 10.21037/atm-21-1005 